\title{
G-protein $\beta 3$ Subunit Gene 825C/T Polymorphism Is Not Associated with Olanzapine-Induced Weight Gain in Korean Schizophrenic Patients
}

\author{
Young-Min Park ${ }^{1}$ \\ Young-Cho Chung ${ }^{1}$ \\ Seung-Hwan Lee ${ }^{1}$ \\ Kang-Joon Lee ${ }^{1}$ \\ Hyun Kim ${ }^{1}$ \\ Jung-Eun $\mathrm{Choi}^{2,3}$ \\ Seung-Gul Kang ${ }^{2}$ \\ Min-Soo Lee ${ }^{2}$ \\ Leen Kim ${ }^{2}$ \\ Heon-Jeong Lee ${ }^{2,3}$ \\ ${ }^{1}$ Department of Psychiatry, \\ Inje University College of Medicine, \\ Goyang, \\ 2Department of Psychiatry and \\ ${ }^{3}$ Division of Brain Korea 21 \\ Biomedical Science, Korea University \\ College of Medicine \\ Seoul, Korea
}

\begin{abstract}
Objective Weight gain is a possible adverse effect of the use of antipsychotics, and is an important factor for long-term health and treatment compliance. Olanzapine is an atypical antipsychotic known to cause considerable weight gain. A relationship between weight gain and the $\mathrm{G}$ protein $\beta 3$ subunit gene (GNB3) $825 \mathrm{C} / \mathrm{T}$ polymorphism has been reported. We therefore examined this possible association in a Korean schizophrenic patient group receiving olanzapine treatment.

Methods Weight and height measurements were obtained prior to starting olanzapine and measured again after long-term treatment. Genotyping for the $825 \mathrm{C} / \mathrm{T}$ polymorphism was performed using a PCR-based method.

Results We found that long-term treatment with olanzapine resulted in mean gains in weight and body mass index (BMI) of $5.2 \mathrm{~kg}$ and $1.93 \mathrm{~kg} / \mathrm{m}^{2}$, respectively. There was a no significant difference in the mean body weight change from baseline to the endpoint after olanzapine treatment between the genotype groups $(\mathrm{p}=0.796)$. There were also no significant differences in genotype or allele frequencies between the severe weight-gain (more than $10 \%$ ) and minimal weight-gain (less than $10 \%$ ) groups $\left(\chi^{2}=0.037, p=0.98 ; \chi^{2}=0.020, p=0.89\right.$ ).

Conclusion The finding from this study thus does not support a relationship between the GNB3 825C/T polymorphism and weight gain in Korean schizophrenic patients receiving olanzapine treatment.
\end{abstract}

KEY WORDS: Olanzapine, Weight, Polymorphism, Schizophrenia.

Psychiatry Invest 2009;6:39-43

\section{Introduction}

Weight gain, as a side effect from the use of atypical antipsychotics, has become a serious problem. More than half of those treated with these drugs will gain at least $10 \%$ of their initial body weight over the course of therapy, and gains of more than $40 \%$ have been reported. ${ }^{1}$ Obesity and weight gain in adulthood are associated with significant health complications such as type II diabetes, coronary heart disease, stroke, gallbladder disease, osteoarthritis, sleep apnea, respiratory problems, and some cancers. ${ }^{2}$ Furthermore, medication-induced weight gain has been associated with a lower quality of life, ${ }^{3,4}$ and is a leading barrier to continued compliance with psychiatric medications. ${ }^{5-7}$ The dibenzodiazepine-derived drugs, such as clozapine and olanzapine, appear to confer the greatest weight-gain liability. Most of the antipsychotic-induced weight gain occurs during the first 6-8 weeks of treatment and reaches a plateau by the end of the first year of treatment. ${ }^{8}$

The underlying mechanisms by which olanzapine and other second-generation antipsychotics cause weight gain remain unclear; however, there are some pharmacological clues, such as roles for the serotonin $(5-\mathrm{HT}),{ }^{9}$ histamine, and adrenergic ${ }^{10}$ 
receptors. These neurotransmitter receptors are therefore good candidates for an association study of antipsychotic-induced obesity. Wang et al. ${ }^{11}$ reported an association between the $\mathrm{G}$ protein $\beta 3825 \mathrm{C} / \mathrm{T}$ polymorphism and longterm clozapine-induced weight change in a Chinese population. Further to this, Bishop et al. ${ }^{12}$ recently reported a clinically significant relationship between GNB3 genotypes and both negative-symptom responses and weight gain in schizophrenic patients treated with olanzapine. However, the results of that study did not reach statistical significance due to the small sample size.

$\mathrm{G}$ proteins are important regulators of the specificity and temporal characteristics of cellular signaling. Heterotrimeric $\mathrm{G}$ proteins are composed of three subunits, which dissociate into constituent $G \alpha$ and $G \beta \gamma$ subunits following receptor activation. ${ }^{13}$ Mutations in the G-protein subunits may therefore contribute to changes in second messenger pathways. ${ }^{14}$ Siffert et al ${ }^{15}$ detected a singlenucleotide polymorphism (SNP) of $825 \mathrm{C} / \mathrm{T}$ in exon 10 of the gene encoding the G-protein $\beta 3$ subunit gene (GNB3). The $\mathrm{G} \beta 3 \mathrm{~s}$ variant has been associated with increased signal transduction and ion transport in the cell, and with pathophysiological conditions such as hypertension, ${ }^{15-19}$ obesity, ${ }^{20,21}$ seasonality, ${ }^{22}$ and depression. ${ }^{23}$ In addition, Dishy et al. ${ }^{24}$ reported an association between the GNB3 825C/ T polymorphism and weight gain during pregnancy. A pharmacogenetic study of sibutramine therapy showed the GNB3 $825 \mathrm{C} / \mathrm{T}$ SNP to be a good predictive marker for weight reduction, ${ }^{25}$ although other similar studies failed to demonstrate this association. ${ }^{17,26,27}$

In light of the previously reported link between the GNB3 825C/T SNP and alterations in body weight regulation, ${ }^{20,28,29}$ we aimed to investigate the relationship between the GNB3 825C/T SNP and olanzapine-induced weight gain in Korean schizophrenic patients.

\section{Methods}

\section{Subjects}

A total of 104 schizophrenic patients were enrolled from the three collaborating hospitals of Korea University Hospital. All subjects were examined by trained psychiatrists using the Korean version of the Structured Clinical Interview for Diagnostic and Statistical Manual of Mental Disorders, fourth edition (DSM-IV) ${ }^{30}$ leading to a diagnosis based on DSM-IV criteria. ${ }^{31}$ Exclusion criteria included evidence of other psychiatric, medical, or neurological illness; family history of diabetes or eating disorders; and age over 65 or under 18 years. Application of these criteria resulted in the exclusion of 25 patients. Therefore 79 patients were included in this study. All the subjects were ethnic Koreans. Some findings from these subjects have been re- ported previously. ${ }^{32-34}$ Written informed consents were obtained, and the study protocol was approved by the Ethics Committee of the Korea University Hospital.

The subjects were weighed prior to starting olanzapine and again after long-term treatment of at least 3 months. The dosage was adjusted individually according to clinical judgment. The use of drugs other than olanzapine was prohibited. Medications such as antipsychotics, mood stabilizers, and antidepressants were avoided during the study due to their potential effects on weight change; however, we combined the use of benzodiazepines or anticholinergics as needed. No subject had received olanzapine or clozapine prior to the present study. The mean daily dose of olanzapine at the end-point examination was $13.6 \mathrm{mg}$ $(\mathrm{SD}=5.3 \mathrm{mg})$.

Other clinical variables that were measured in the study were gender, age, olanzapine treatment duration and dosages, and previous antipsychotics dosages (expressed as chlorpromazine equivalents). Changes in body weight and body mass index (BMI) during the treatment were also calculated.

\section{Genotyping}

Genomic DNA was extracted from leukocytes of the study subjects using a QIAamp Blood Kit (Qiagen, Germany). A polymerase chain reaction (PCR)-based method was used for genotyping of the GNB3-gene $825 \mathrm{C} / \mathrm{T}$ polymorphism. $^{15,23}$

\section{Statistical analyses}

Differences in allele frequencies between cohorts with different body weight changes were evaluated by a chisquare analysis. The association of genotype with weight gains and changes in BMI was assessed by univariate analysis of variance (ANOVA) or Student's t-test. All of the analyses were performed using standard software (SPSS for Windows), and probability values of $\mathrm{p}<0.05$ were considered statistically significant.

\section{Results}

Genotype frequencies in our sample were not deviated from Hardy-Weinberg equilibrium $\left(\chi^{2}=0.008, p=0.93\right)$. The sociodemographics, initial body weight and BMI, olanzapine dosage, previous antipsychotic dosages, and treatment duration did not differ between the genotype groups. There was a no significant difference in the mean body weight change from baseline to the endpoint after olanzapine treatment between the genotype groups $(\mathrm{p}=0.796)$. When we divided the subjects into two groups, the T-allele carriers (the TT and CT genotypes) and the T-allele noncarriers (the $\mathrm{CC}$ genotype), the mean changes in body 
YM Park et al.

TABLE 1. Demographic and clinical variables of 79 schizophrenic patients in the three genotype groups

\begin{tabular}{|c|c|c|c|c|c|c|}
\hline & \multicolumn{3}{|c|}{ Genotype } & \multicolumn{2}{|c|}{ ANOVA } & \multirow{2}{*}{$\frac{T+\text { vs. } T-}{p}$} \\
\hline & $\mathrm{CC}(\mathrm{N}=22)$ & $\mathrm{CT}(\mathrm{N}=39)$ & $\mathrm{TT}(\mathrm{N}=18)$ & $\mathrm{F}$ & $\mathrm{p}$ & \\
\hline Age & $42.9 \pm 11.25$ & $49.3 \pm 11.0$ & $45.2 \pm 12.6$ & 2.36 & 0.103 & 0.083 \\
\hline Sex (male/female) & $16 / 6$ & $25 / 14$ & $12 / 6$ & $\chi^{2}=0.48$ & 0.788 & 0.508 \\
\hline Previous antipsychotics (mg/day)* & $765.63 \pm 492.86$ & $662.5 \pm 426.92$ & $725.0 \pm 379.65$ & 0.322 & 0.726 & 0.505 \\
\hline Baseline body weight (kg) & $64.9 \pm 12.4$ & $64.7 \pm 11.8$ & $65.0 \pm 13.8$ & 0.005 & 0.995 & 0.96 \\
\hline Baseline BMI $\left(\mathrm{kg} / \mathrm{m}^{2}\right)$ & $23.10 \pm 3.53$ & $23.81 \pm 3.90$ & $23.60 \pm 3.63$ & 0.253 & 0.777 & 0.49 \\
\hline Treatment duration (days) & $414.36 \pm 257.2$ & $450.6 \pm 308.8$ & $449.6 \pm 292.66$ & 0.121 & 0.887 & 0.623 \\
\hline Olanzapine dosage (mg/day) & $14.1 \pm 4.9$ & $13.6 \pm 5.40$ & $14.8 \pm 4.7$ & 0.347 & 0.705 & 0.925 \\
\hline Weight change $(\mathrm{kg})$ & $6.18 \pm 8.66$ & $4.88 \pm 6.32$ & $5.26 \pm 7.15$ & 0.228 & 0.796 & 0.515 \\
\hline Weight change (\%) & $9.84 \pm 13.08$ & $8.35 \pm 11.48$ & $8.74 \pm 13.14$ & 0.103 & 0.902 & 0.657 \\
\hline BMI change $\left(\mathrm{kg} / \mathrm{m}^{2}\right)$ & $2.13 \pm 2.77$ & $1.87 \pm 2.48$ & $1.90 \pm 2.75$ & 0.072 & 0.930 & 0.704 \\
\hline
\end{tabular}

Values represent mean \pm SD. *Chlorpromazine equivalents. ANOVA: analysis of variance, BMl: body mass index

TABLE 2. Comparison of the GNB3 genotypes and allele frequencies between higher $(>10 \%)$ and lower weight gain $(<10 \%)$

\begin{tabular}{|c|c|c|c|c|c|c|c|}
\hline & \multicolumn{4}{|c|}{ Genotype } & \multicolumn{3}{|c|}{ Allele frequency } \\
\hline & $\mathrm{CC}$ & CT & $T T$ & & C & $T$ & \\
\hline Weight gain >10\% & 9 & 15 & 7 & $\chi^{2}=0.037$ & 0.53 & 0.47 & $\chi^{2}=0.020$ \\
\hline Weight gain < $10 \%$ & 13 & 24 & 11 & $p=0.98$ & 0.52 & 0.48 & $p=0.89$ \\
\hline
\end{tabular}

weight from baseline to endpoint after olanzapine treatment were still not significantly different $(\mathrm{p}=0.515)$. The other clinical variables did not differ significantly between the two groups (Table 1). There were also no significant differences in genotype or allele frequencies between the severe weight-gain (more than $10 \%$ ) and minimal weightgain (less than $10 \%)$ groups $\left(\chi^{2}=0.037, \mathrm{p}=0.98 ; \chi^{2}=0.020\right.$, $\mathrm{p}=0.89$ )(Table 2).

\section{Discussion}

One of candidate genes for an association with obesity is the heterotrimeric G proteins, which are key components of intracellular signal transduction and play a focal role in adipogenesis. ${ }^{2,35,36}$ A previous study showed that the GNB3 $825 \mathrm{C} / \mathrm{T}$ variant influences lipolysis. ${ }^{37}$ In the heterotrimeric $\mathrm{G}$ protein complex, the $\beta$ subunit of the $\mathrm{G}$ protein complex is common for both $\mathrm{G}_{\mathrm{s}}$ and $\mathrm{G}_{\mathrm{i}}$ complexes, and is ubiquitously expressed..$^{38}$ Therefore, a functional variation in GNB3 may influence the action of $\mathrm{G}_{\mathrm{s}}$ - as well as $\mathrm{G}_{\mathrm{i}}$-coupled receptors. The $\beta_{1}$ - and $\beta_{2}$-adrenoceptors ( $\mathrm{G}_{\mathrm{s}}$-coupled), and $\beta_{2 \mathrm{a}}$-adrenoceptors $\left(\mathrm{G}_{\mathrm{i}}\right.$-coupled) coexist in human fat cells, where they activate and inhibit lipolysis, respectively. ${ }^{37}$ The $825 \mathrm{~T}$ allele of the GNB3 gene appears to decrease the production of GNB3 in fat cells and thereby inhibit lipolysis via $\beta_{1^{-}}, \beta_{2^{-}}$, and $\beta_{2 \mathrm{a}}$-adrenoceptor signaling. ${ }^{37}$ From a study of post-pregnancy weight retention, Gutersohn et al. ${ }^{28}$ reported that subjects with a GNB3 $825 \mathrm{~T} / \mathrm{T}$ genotype are at high risk for obesity and post-pregnancy weight retention if they do not exercise regularly. The $825 \mathrm{~T}$ allele of the GNB3 gene is associated with an increased BMI across different ethnicities, and apparently represents a "thrifty genotype". ${ }^{20,21}$ Several studies, ${ }^{20,21,28,37,39}$ have reported a significant relationship between the GNB3 $825 \mathrm{C} / \mathrm{T}$ polymorphism and obesity or fat metabolism. In contrast, Suwazono et al.$^{40}$ reported that the GNB3 825C/T SNP was not a significant factor in being overweight for 2,625 Japanese people. In addition, Tsai et al. ${ }^{41}$ reported that the GNB3 $825 \mathrm{C} / \mathrm{T}$ SNP was not significant in clozapineinduced body-weight change. In the present study, we also did not find a sig-nificant association between GNB 825C/T SNP and olanzapineinduced weight gain, which was consistent with the previous Asian studies. ${ }^{40,41}$ It is possible that there are ethnic differences in the relationship between GNB3 825C/T SNP and obesity; however, recently, Ujike et al. ${ }^{42}$ reported the 825T allele of GNB3 was significantly associated with olanzapine-induced weight gain in 164 Japanese schizophrenic patients. Very recently, Souza et al ${ }^{43}$ investigated the association of the GNB3 and antipsychotic-induced weight gain using meta-analytical techniques. Their analysis of 18,903 subjects showed no significant association although there was a trend associating $\mathrm{CC}$ and lower BMI under a fixed model. Therefore, this relationship remains controversial.

The major limitation of this work was that our patients had already received traditional antipsychotics prior to the study, and therefore any tendency to weight gain may have been triggered already. However, we observed that the chlorpromazine-equivalent doses of the previous antipsychotics, baseline body weight, and baseline BMI did not differ between the genotypes. The second issue was that the duration of medication was not the same among our study cohorts, possibly influencing the results. We do not believe, however, that any such effect would be significant, because there was no difference in duration of olan- 
zapine treatment between the genotype groups, and previous studies reported that most weight gain occurred during the first 6-8 weeks of olanzapine therapy ${ }^{8}$ Third, we did not assess and control caloric intake in the subjects (including caloric counts and meal refusals) due to the nature of a long-term study. Finally, the relatively small sample size studied here limits the generality of our findings.

Additional studies using larger sample sizes and better medication control are needed. It will also be necessary to evaluate the possible involvement of an as-yet-uncovered gene(s) that influence susceptibility to olanzapine-induced weight gain as well as the possibility of gene-gene interactions.

\section{REFERENCES}

1. Umbricht D, Kane JM. Medical complications of new antipsychotic drugs. Schizophr Bull 1996;22:475-483.

2. Allison DB, Mentore JL, Heo M, Chandler LP, Cappelleri JC, Infante $\mathrm{MC}$, et al. Antipsychotic-induced weight gain: a comprehensive research synthesis. Am J Psychiatry 1999;156:1686-1696.

3. Allison DB, Mackell JA, McDonnell DD. The impact of weight gain on quality of life among persons with schizophrenia. Psychiatr Serv 2003;54:565-567.

4. Strassnig M, Brar JS, Ganguli R. Body mass index and quality of life in community-dwelling patients with schizophrenia. Schizophr Res 2003; 62:73-76.

5. Perkins DO. Adherence to antipsychotic medications. J Clin Psychiatry 1999; 60 Suppl 21:25-30.

6. Vauth R, Löschmann C, Rüsch N, Corrigan PW. Understanding adherence to neuroleptic treatment in schizophreniai. Psychiatry Res 2004; 126:43-49.

7. Jibson MD, Tandon R. New atypical antipsychotic medications. J Psychiatr Res 1998;32: 215-228.

8. Nasrallah H. A review of the effect of atypical antipsychotics on weight. Psychoneuroendocrinology 2003;28 Suppl 1:83-96.

9. Ellingrod VL, Perry PJ, Ringold JC, Lund BC, Bever-Stille K, Fleming $\mathrm{F}$, et al. Weight gain associated with the $-759 \mathrm{C} / \mathrm{T}$ polymorphism of the $5 \mathrm{HT} 2 \mathrm{C}$ receptor and olanzapine. Am J Med Genet B Neuropsychiatr Genet 2005;134B:76-78.

10. Casey DE, Zorn SH. The pharmacology of weight gain with antipsychotics. J Clin Psychiatry 2001;62 Suppl 7:4-10.

11. Wang YC, Bai YM, Chen JY, Lin CC, Lai IC, Liou YJ. C825T polymorphism in the human $\mathrm{G}$ protein beta3 subunit gene is associated with long-term clozapine treatment-induced body weight change in the Chinese population. Pharmacogenet Genomics 2005;15:743-748.

12. Bishop JR, Ellingrod VL, Moline J, Miller D. Pilot study of the Gprotein beta3 subunit gene $(\mathrm{C} 825 \mathrm{~T})$ polymorphism and clinical response to olanzapine or olanzapine-related weight gain in persons with schizophrenia. Med Sci Monit 2006;12:BR47-B50.

13. Simon MI, Strathmann MP, Gautam N. Diversity of G proteins in signal transduction. Science 1991;252:802-808.

14. Ram A, Guedj F, Cravchik A, Weinstein L, Cao Q, Badner JA, et al. No abnormality in the gene for the $G$ protein stimulatory alpha subunit in patients with bipolar disorder. Arch Gen Psychiatry 1997;54:44-48.

15. Siffert W, Rosskopf D, Siffert G, Busch S, Moritz A, Erbel R, et al. Association of a human G-protein beta3 subunit variant with hypertension. Nat Genet 1998;18:45-48.

16. Siffert W. G-protein beta3 subunit $825 \mathrm{~T}$ allele and hypertension. Curr Hypertens Rep 2003;5:47-53.

17. Benjafield AV, Lin RC, Dalziel B, Gosby AK, Caterson ID, Morris BJ. G-protein beta3 subunit gene splice variant in obesity and overweight.
Int J Obes Relat Metab Disord 2001;25:777-780.

18. Dong Y, Zhu H, Sagnella GA, Carter ND, Cook DG, Cappuccio FP. Association between the C825T polymorphism of the $\mathrm{G}$ protein beta3subunit gene and hypertension in blacks. Hypertension 1999;34:11931196.

19. Hengstenberg C, Schunkert H, Mayer B, Döring A, Löwel H, Hense $\mathrm{HW}$, et al. Association between a polymorphism in the $\mathrm{G}$ protein beta3 subunit gene (GNB3) with arterial hypertension but not with myocardial infarction. Cardiovasc Res 2001;49:820-827.

20. Siffert W, Förster P, Jöckel KH, Mvere DA, Brinkmann B, Naber C, et al. Worldwide ethnic distribution of the $\mathrm{G}$ protein beta3 subunit $825 \mathrm{~T}$ allele and its association with obesity in Caucasian, Chinese, and Black African individuals. J Am Soc Nephrol 1999;10:1921-1930.

21. Hegele RA, Anderson C, Young TK, Connelly PW. G-protein beta3 subunit gene splice variant and body fat distribution in Nunavut Inuit. Genome Res 1999;9:972-977.

22. Lee HJ, Sung SM, Han CS, Kim YK, Kim SH, Lee MS, et al. Gprotein beta3 subunit $\mathrm{C} 825 \mathrm{~T}$ polymorphism tends to be associated with seasonal variation in young male college students. Neuropsychobiology 2005;52:135-139.

23. Zill P, Baghai TC, Zwanzger P, Schüle C, Minov C, Behrens S, et al. Association analysis of a polymorphism in the G-protein stimulatory alpha subunit in patients with major depression. Am J Med Genet 2002;114:530-532.

24. Dishy V, Gupta S, Landau R, Xie HG, Kim RB, Smiley RM, et al. Gprotein beta(3) subunit $825 \mathrm{C} / \mathrm{T}$ polymorphism is associated with weight gain during pregnancy. Pharmacogenetics 2003;13:241-242.

25. Hauner H, Meier M, Jöckel KH, Frey UH, Siffert W. Prediction of successful weight reduction under sibutramine therapy through genotyping of the G-protein beta3 subunit gene (GNB3) C825T polymorphism. Pharmacogenetics 2003;13:453-459.

26. Hinney A, Geller F, Neupert T, Sommerlad C, Gerber G, Gorg T, et al. No evidence for involvement of alleles of the $825-\mathrm{C} / \mathrm{T}$ polymorphism of the G-protein subunit beta 3 in body weight regulation. Exp Clin Endocrinol Diabetes 2001;109:402-405.

27. Poston WS, Haddock CK, Spertus J, Catanese DM, Pavlik VN, Hyman DJ, et al. Physical activity does not mitigate G-protein-related genetic risk for obesity in individuals of African descent. Eat Weight Disord 2002;7:68-71.

28. Gutersohn A, Naber C, Müller N, Erbel R, Siffert WG. G protein beta3 subunit 825 TT genotype and post-pregnancy weight retention. Lancet 2000;355:1240-1241.

29. Hocher B, Slowinski T, Stolze T, Pleschka A, Neumayer H, Halle H. Association of maternal $\mathrm{G}$ protein beta3 subunit $825 \mathrm{~T}$ allele with low birthweight. Lancet 2000;355:1241-1242.

30. Han OS, Hong JP. Structured clinical interview for DSM-IV Axis I Disorder - Korean version. Seoul: Hana Medical Publishing; 2000.

31. American Psychiatric Association. Diagnostic and statistical manual of mental disorders: DSM-IV, $4^{\text {th }}$ ed. Washington DC: American Psychiatric Association; 1994.

32. Park YM, Chung YC, Lee SH, Lee KJ, Kim H, Byun YC, et al. Weight gain associated with the alpha2a-adrenergic receptor $-1,291 \mathrm{C} / \mathrm{G}$ polymorphism and olanzapine treatment. Am J Med Genet B Neuropsychiatr Genet 2006;141B:394-397.

33. Park YM, Cho JH, Kang SG, Choi JE, Lee SH, Kim L, et al. Lack of association between the $-759 \mathrm{C} / \mathrm{T}$ polymorphism of the 5-HT2C receptor gene and olanzapine-induced weight gain among Korean schizophrenic patients. J Clin Pharm Ther 2008;33:55-60.

34. Kang SG, Lee HJ, Park YM, Choi JE, Han C, Kim YK, et al. Possible association between the $-2548 \mathrm{~A} / \mathrm{G}$ polymorphism of the leptin gene and olanzapine-induced weight gain. Prog Neuropsychopharmacol Biol Psychiatry 2008;32:160-163.

35. Malbon CC. Heterotrimeric G-proteins and development. Biochem Pharmacol 1997;53:14.

36. Comuzzie AG, Allison DB. The search for human obesity genes. 
Science 1998;280:1374-1377.

37. Rydén M, Faulds G, Hoffstedt J, Wennlund A, Arner P. Effect of the (C825T) Gbeta(3) polymorphism on adrenoceptor-mediated lipolysis in human fat cells. Diabetes 2002;51:1601-1608.

38. Gautam N, Downes GB, Yan K, Kisselev O. The G-protein betagamma complex. Cell Signal 1998;10:447-455.

39. Siffert W. G protein beta 3 subunit $825 \mathrm{~T}$ allele, hypertension, obesity, and diabetic nephropathy. Nephrol Dial Transplant 2000;15:1298-1306

40. Suwazono Y, Okubo Y, Kobayashi E, Miura K, Morikawa Y, Ishizaki $\mathrm{M}$, et al. Lack of association between human G-protein beta3 subunit variant and overweight in Japanese workers. Obes Res 2004;12:4-8.
41. Tsai SJ, Yu YW, Lin CH, Wang YC, Chen JY, Hong CJ. Association study of drenergic beta3 receptor (Trp64Arg) and G-protein beta3 subunit gene (C825T) polymorphisms and weight change during clozapine treatment. Neuropsychobiology 2004;50:37-40.

42. Ujike H, Nomura A, Morita Y, Morio A, Okahisa Y, Kotaka T, et al. Multiple genetic factors in olanzapine-induced weight gain in schizophrenia patients: a cohort study. J Clin Psychiatry 2008; 69:1416-1422.

43. Souza RP, De Luca V, Muscettola G, Rosa DV, de Bartolomeis A, Romano Silva M, et al. Association of antipsychotic induced weight gain and body mass index with GNB3 gene: a meta-analysis. Prog Neuropsychopharmacol Biol Psychiatry 2008;32:1848-1853. 